\title{
Internet Usage Habits and Internet Usage in Educational Studies of Vocational School Students
}

\author{
Zehra Deniz YAKINCI 1(D), Perihan GÜRBÜZ 2(D),Gülsüm YETIŞ ${ }^{3 *}$ \\ ${ }^{1}$ Inonu University, Vocational School of Health Service, deniz.yakinci@inonu.edu.tr \\ ${ }^{2}$ Inonu University, Vocational School of Health Service, perihan.gurbuz@inonu.edu.tr \\ ${ }^{3}$ Inonu University, Vocational School of Health Service, gulsum.yetis@inonu.edu.tr \\ * Corresponding Author: gulsum.yetis@inonu.edu.tr
}

\begin{tabular}{|c|c|}
\hline \multicolumn{2}{|l|}{ Article Info } \\
\hline \multicolumn{2}{|r|}{ July 26, 2017} \\
\hline Accepted: & December 18, 2017 \\
\hline Online: & 30 April, 2018 \\
\hline \multicolumn{2}{|c|}{$\begin{array}{l}\text { Keywords: internet usage habit, } \\
\text { internet usage in educational studies, } \\
\text { vocational school students, young } \\
\text { internet addiction test }\end{array}$} \\
\hline
\end{tabular}

\begin{abstract}
Internet is the easiest way to access information. It provides positive contributions to individual and surroundings in learning and information era. At this point, the answers of the questions: "How do young people use internet and how much do they use internet for their education?" come into prominence. In former researches, although internet has been shown to be used for educational purposes, there exists statistical differences in many topics as; internet usage ratios, gender usage habits, time spent on internet.

Our aim was to determine vocational school students' internet usage habits and internet usage in educational studies. 388 Inonu University Health Services Vocational School students' of 2016-2017 academic year were included to this descriptive type of study. We performed survey method. A questionnaire prepared by researchers and Young Internet Addiction Test- Short Form (YIAT-SF) was used. We found internet addiction rate as $3.4 \%$ and the average internet usage was 5 hours daily. When students were asked to enumerate the internet sites they use, the result was: social media, news sites, movie and series sites, educational and informational content sites, play sites, e-mail, shopping sites, and sexual content sites in order of usage preference. Social media was preferred by $79.4 \%$ in the first place, educational content sites were preferred in the first place by $5.7 \%$. The second most frequently used sites were movie and series sites $(22.8 \%)$. Educational/informational content $(20.2 \%)$ sites were the fifth preferred sites in the preference order.
\end{abstract} vocational school students. Journal of Computer and Education Research, 6 (11), 33-46. https://doi.org/10.18009/jcer.330925 


\section{Introduction}

Internet is a world-wide, ever-growing network of interconnected computer systems. The place of the internet in daily life is undisputed. Computer and information technologies are increasing rapidly and becoming widespread. Global number of internet users reached 2,3 billion by 2011, this number has been obtained as 3,7 billion by March 2017 (World Internet Usage and Population Statistics- IWS, 2017). Internet usage ratio has been found to have increased 96,3\% between the years 2000-2017 (IWS, 2017). Internet is used for various purposes such as communication and information in general terms. According to the researchs -about technology's educational effectiveness-, educational technology can provide benefits to students of all ages when used correctly. By the beginning of the $21^{\text {st }}$ century -so called information century-, the developments in information technology increase in a rapid manner. Nowadays, many universities in the world provide education through internet. The teachers accept the educational materials on the internet as; attractive, interesting and useful to evaluate (Shin, 2014). Many educators in higher education programmes share lecture notes, essay exams and other visual aids through web sites. Besides reaching the educators' lectures and latest scientific researches, internet is also used for discussions, sharing and face-to-face training. Practices such as tests, forms, databases and discussion rooms, message boards are used successfully in face-to-face training (Akbaba \& Altun, 2000; Altun, 2003). Usage of computer and internet in appropriate and efficient way also increases the students'; problem solving- writing, communication and critical thinking abilities (Ergün, 1998). In accordance of these information we can say that, the skills of students in computer\& internet usage are becoming more advantageous in their post-graduate lives (Altun, 2003).

University students are getting highest level of education among community and are expected to use developments in their daily life. There are many researches among students about internet usage in education (Arıkan \& Altun, 2007; Dursun, 2004; Filiz, Erol, Dönmez, \& Kurt, 2014; Nath, Naskar, \& Viktor, 2016). Although students have been shown to use internet for searching and preparing homework (Arikan \& Altun, 2007) (Ersun, et al., 2010) in some studies, it is seen that university students do not benefit from this technology adequately (Filiz, et al., 2014; Nath, et al., 2016).

Besides the positive effects of internet usage (Naseri, et al., 2015), it has been seen that incorrect internet usage may cause educational problems such as decreased school performance and network- related maladaptive cognition (Akdağ, Şahan, Y1lmaz, Özhan, \& 
Şan, 2014; Nath, et al., 2016), social dysfunction (Chen, Quan, Lu, Fei, \&Li, 2015), internet addiction (Prasad, et al., 2017). In a recent study, it has been shown that there is a vicious cycle between internet addiction and network- related maladaptive cognition in college students (Han, et al., 2017).

At this perspective, to obtain internet usage habits of college students will not only provide positive support in internet education programmes but also will give ideas about unfavorable effects of internet usage and ideal education approaches about internet usage. In this research our aim was to determine vocational school students' internet usage habits and internet usage in educational studies.

\section{Method}

Type of Research, Universe and Sampling

We performed this descriptive type of study with 'Inonu University Health Services Vocational School students' of 2016-2017 academic year. Our aim was to reach whole of the universe (480 students), without using sample selection method. However, those who did not agree to participate in the survey and those who did not attend the school at the time of the survey were excluded, and 388 students formed the sample of the research.

\section{Research method}

We used survey method in the research. A questionnaire and YIAT- SF were performed. The questionnaire was composed of; 10 questions about students' sociodemographic characteristics and 8 questions about internet usage habits (time spent on the internet, internet sites preferred, internet usage for education purposes). Questionnaires were answered in 5-10 minutes by students and the filled forms were collected by the researchers.

\section{Data Form}

In the study; a questionnaire prepared by researchers -using literature information(Savc1, 2017) and "Young Internet Addiction Test-Short Form" were used. The questionnaire was composed of 18 questions about students' socio-demographic characteristics and internet usage habits.

Young Internet Addiction Test- Short Form (YIAT-SF): YIAT-SF has been developed by Young (Young, 1998) and transformed into a short form by Pawlikowski and colleagues (Pawlikowski, Altstötter-Gleich \& Brand, 2013). It consists of 12 items and has five Likert $(1=$ never $-5=$ Always) type of measurement (Kutlu, Savc1, Demir \& Aysan, 2016). There is no 
counter substance in the scale. It's Turkish adaptation has been made by Kutlu and colleagues. Confirmatory factor analysis study about validity - reliability showed YIAT-SF to have well adaptation and the reliability coefficient of internal consistency was calculated as 0.85 (Kutlu, et al., 2016). In this study, the Cronbach alpha internal consistency coefficient was found to be over 0.84 for each question and 0.86 for all of the scale questions. The results from the reliability and validity studies indicate that the reliability and validity of the YIATSF are met. Scores that can be taken from the scale, range from 12 to 60 . The higher scores indicate internet dependency to be higher.

\section{Data Collection}

The data were collected in the classroom environment by distributing data forms during off-hours in January 2017.

\section{Ethical Permissions}

Prior to the implementation of the research, written permissions were taken from "The Ethics Committee of Malatya Clinical Researches" and from "Inonu University Vocational School of Health Services". Oral permissions of the students who were volunteerly included to the study were taken before performing the survey.

\section{Statistical Analysis}

The statistical analyzes of the obtained data were performed by SPSS 17.0 package program in computer environment. Descriptive statistics (number, percentage, mean, standard deviation), independent $\mathrm{t}$ test, Kruskal-Wallis, Mann-Whitney $\mathrm{U}$ test and ANOVA variance analysis tests were used in the evaluation of socio-demographic characteristics of the students. The results were evaluated in a confidence interval of $95 \%$ and a significance level of $\mathrm{p}<0.05$.

\section{Findings and Interpretation}

$65.2 \%$ of the 388 students who participated in the research were girls, $70,6 \%$ of them defined their economic status as moderate, $69,6 \%$ were in the age range of 18-20 years (Table 1) and the average age was 20.66. When we looked at the demographic characteristics of the parents, we found that; $45,2 \%$ of mothers and $29,9 \%$ of fathers were graduated from primary school, $93.5 \%$ of mothers were housewives, $40.8 \%$ of fathers were self-employed. $52.3 \%$ of the students were living with their families. It was determined that; $77,1 \%$ of the students had a body mass index (BMI) of 19-24, 7,00\% of them were equal or below 18 and 16,00\% were 
equal or over 25 (Table 1). 43,7\% of the students did not do sports and $29,1 \%$ did not have reading habit in their routine lives (Table 1$)$.

Table 1. Students' Descriptive Features

\begin{tabular}{lcc}
\hline Descriptive features & f & (\%) \\
\hline Gender & 253 & 65,2 \\
Girl & 135 & 34,8 \\
Male & & \\
\hline Age & 270 & 69,6 \\
Between 18 and 20 & 118 & 30,4 \\
21 years and older & & \\
Economical situation & 76 & 19,6 \\
Good & 274 & 70,6 \\
Moderate & 37 & 9,6 \\
Bad & & \\
\hline Place of Residence & 202 & 52,1 \\
With family & 111 & 28,6 \\
Dormitary & 50 & 12,9 \\
Student house & 23 & 5,9 \\
Other & & \\
\hline Body Mass Index & 27 & 7,0 \\
Lean & 299 & 77,1 \\
Average & 62 & 16,0 \\
Fat & & \\
\hline Sports & 218 & 56,3 \\
Yes & 169 & 43,7 \\
\hline No & & \\
Reading habit & 275 & 70,9 \\
No & 113 & 29,1 \\
\hline
\end{tabular}

Age of meeting internet was between 5-33 years. The average duration of the students' internet connection was 5 hours daily. $36,8 \%$ of the students used internet mostly in the evening hours, $67,8 \%$ said that they used internet mostly from their mobile phones and $94,3 \%$ of the students had internet connection in their mobile phones.

Of the students, $60,1 \%$ had eating attitude during internet usage. The things eaten and/or drunk during internet usage were; $38.9 \%$ cookies, $33,2 \%$ fruit, $31,7 \%$ carbonated drinks, $28,6 \%$ chips, $26,8 \%$ meal, $21,4 \%$ fastfood. $50,8 \%$ of the students had internet restricting factors, and $21,1 \%$ of the students defined the main internet restricting factor as school (Figure 1). 


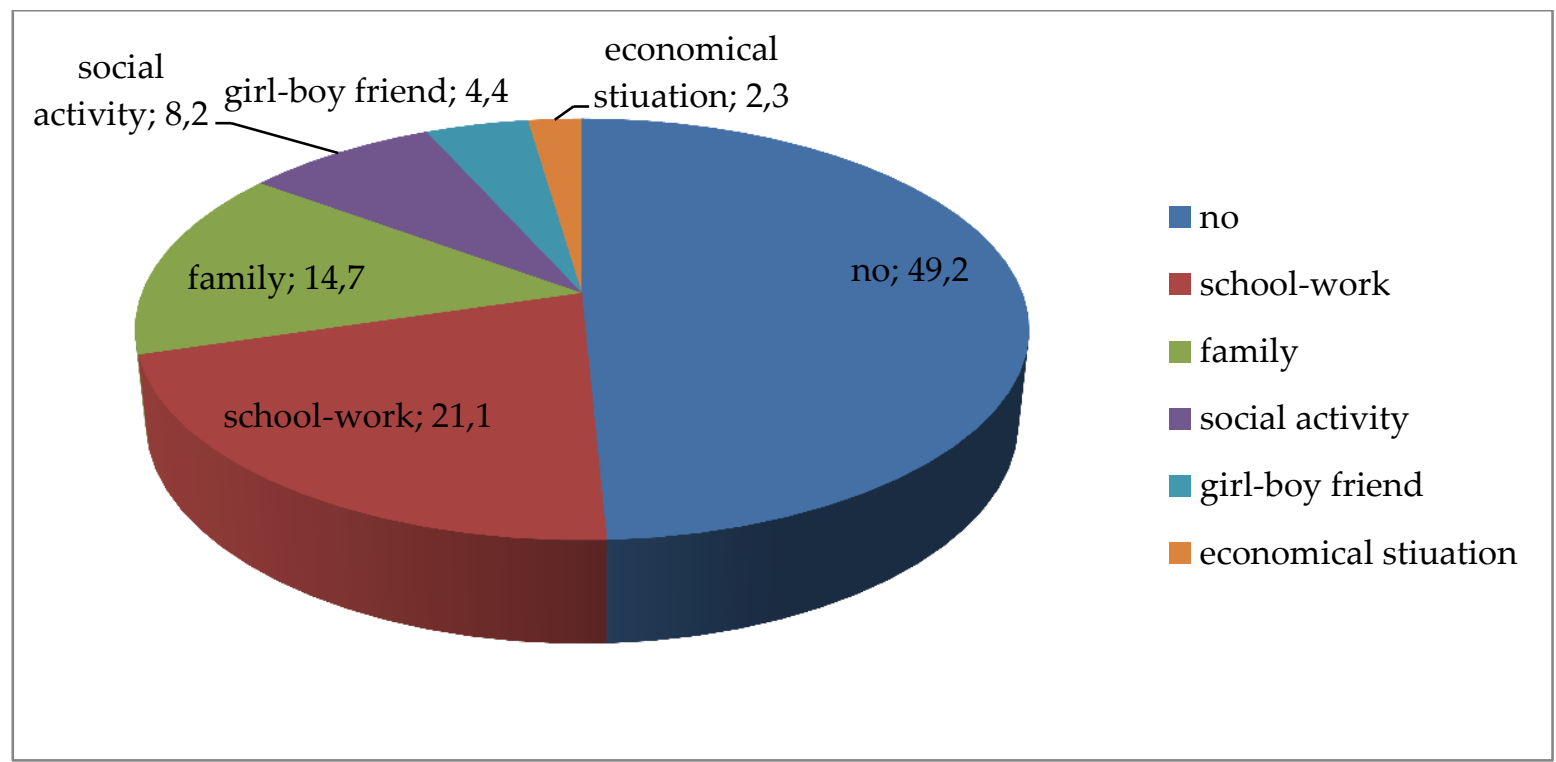

Figure 1: Factors Restricting Internet Usage by Students $(50,8 \%$ of the students defined to have internet restricting factors, 49,2 did not have restricting factor-blue in graphic-. Restrictive factors are shown in different colours.).

Table 2. Students' Internet Site Preference Rank

\begin{tabular}{lllllllll}
\hline Internet site usage ratio & $\mathbf{1 .}$ & $\mathbf{2 .}$ & $\mathbf{3 .}$ & $\mathbf{4 .}$ & $\mathbf{5 .}$ & $\mathbf{6 .}$ & $\mathbf{7 .}$ & $\mathbf{8 .}$ \\
\hline Social media platforms & 79,4 & 5,9 & 4,4 & 1,9 & 3,0 & 2,0 & 1,6 &, 8 \\
Movie, series sites & 5,2 & 22,8 & 25,9 & 20,4 & 13,7 & 9,1 & 5,5 & 75,4 \\
News sites & 3,9 & 22,5 & 17,4 & 22,7 & 19,3 & 11,6 & 6,6 &, 8 \\
Sites with training / & 5,7 & 17,7 & 17,8 & 19,3 & 20,2 & 14,6 & 5,5 &, 8 \\
Information content & & & & & & & & \\
Game sites & 4,4 & 11,8 & 10,9 & 8,9 & 7,7 & 21,7 & 23,0 & 2,5 \\
E-mail &, 5 & 7,6 & 5,3 & 9,3 & 17,6 & 20,2 & 33,9 & 5,1 \\
Shopping sites &, 5 & 10,7 & 17,8 & 16,0 & 16,7 & 19,2 & 19,7 & 10,4 \\
Sexual sites &, 5 & 1,1 &, 6 & 1,5 & 1,7 & 1,5 & 4,4 & 4,0 \\
\hline Total & 100 & 100 & 100 & 100 & 100 & 100 & 100 & 100 \\
\hline
\end{tabular}

Preferred internet sites in order of preference were; social media $(79.4 \%)$, movie and series sites (the second, third and eight most preferred, percentage ratios in order: $22.8 \%$, $25.9 \%, 75.4 \%)$, news sites (22.7\%), education sites (20.2), game sites $21.7 \%$ and e-mail control $(33.9 \%)$ (Table 2, Figure 2). 


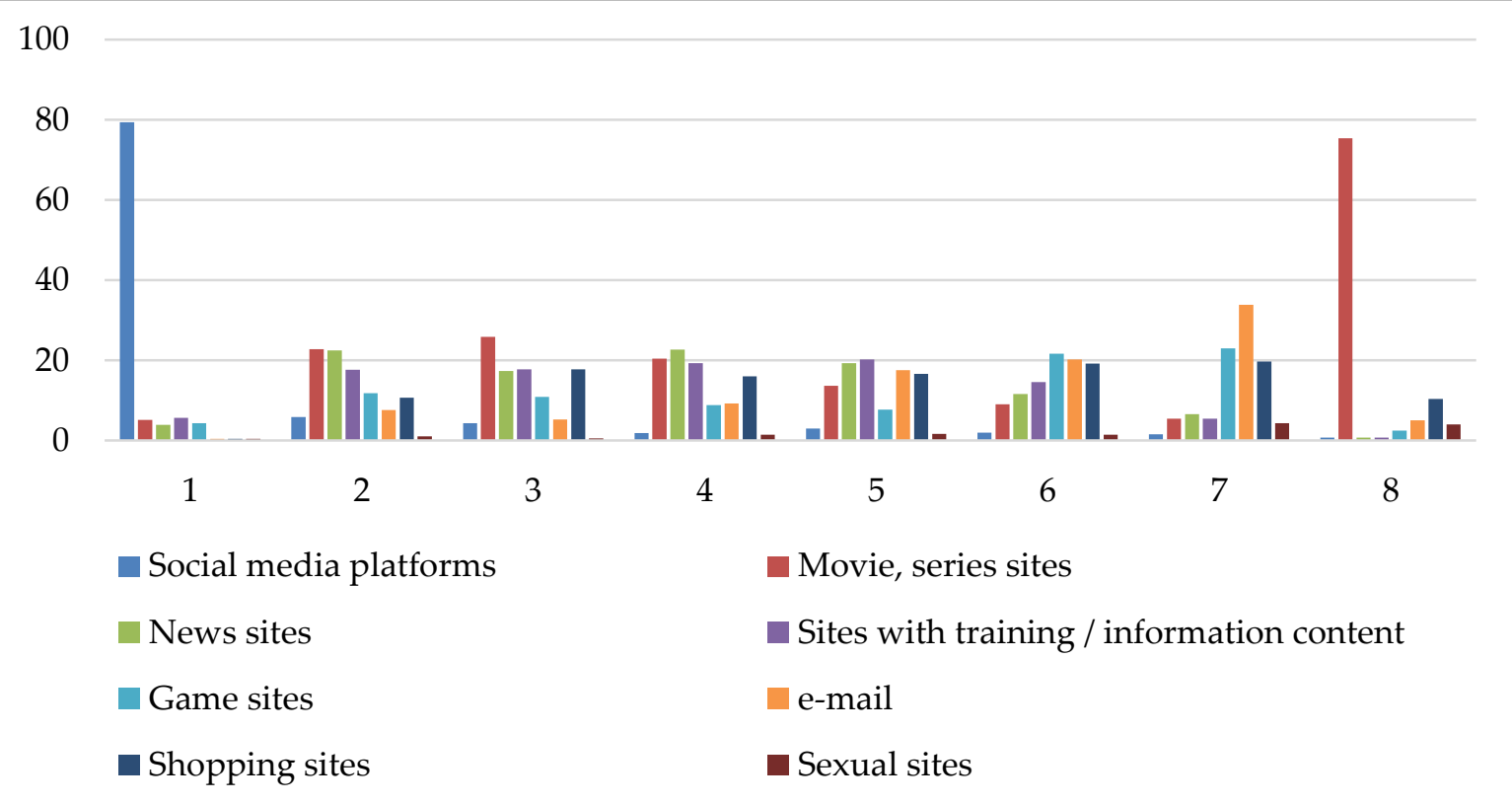

Figure 2: Students' Internet Site Preference Rank'. The numbers in the X plane defines the preference priorities of students'. " 1 " means the preference ratio of internet sites as the first choice. " 2 " means the preference ratio of the second choices, this is same for all eight choices -as shown in Table 1 as 'Students' Internet Site Preference Rank'

Table 3. Evaluation of Internet Addiction Status of Students

\begin{tabular}{lll}
\hline Internet Score Averages & $\mathbf{f}$ & $\mathbf{\%}$ \\
\hline $12-27$ points & 200 & 51,5 \\
$28-44$ points & 175 & 45,1 \\
$45-60$ points & 13 & 3,4 \\
\hline
\end{tabular}

When the average YIAT-SF scores of the students were examined; $51.5 \%$ of them were in the range of $12-27$ points, $45.1 \%$ had $28-44$ points. Shown in table 3 (Evaluation of Internet Addiction Status of Students), 3.4\% were in the range of 45-60 points and this can be defined as "very high risk of addiction" (Table 3, Figure 3) .

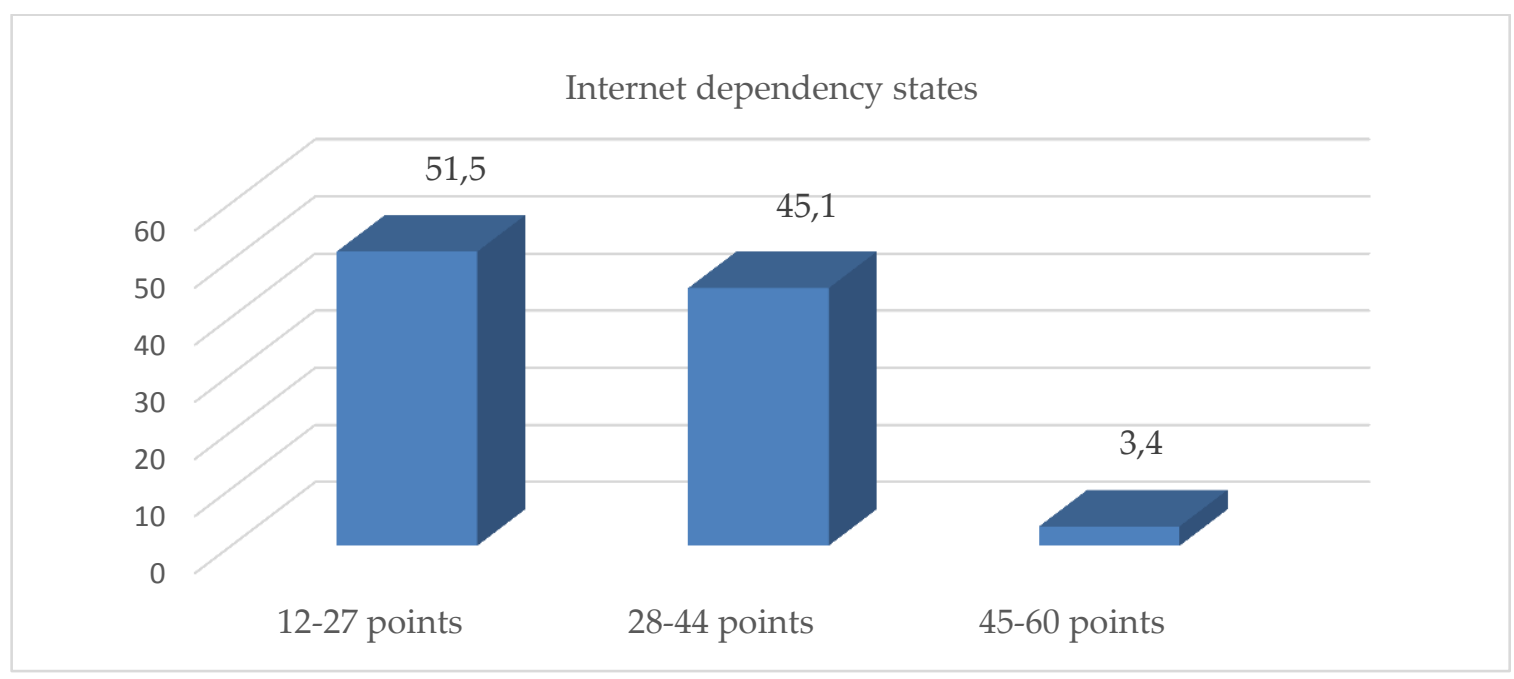

Figure 3. Evaluation of Students' Internet Addiction Situations 
Yaknct, Gürbüz \& Yetiş

Table 4. Comparison of Young Internet Addiction Scale Average of Students according to Internet Usage Characteristics

\begin{tabular}{|c|c|c|c|c|c|}
\hline \multirow[t]{2}{*}{ Descriptive features } & \multirow[t]{2}{*}{ f } & \multirow[t]{2}{*}{$(\%)$} & \multicolumn{2}{|c|}{ Addiction Scale average } & \multirow[t]{2}{*}{ Significance } \\
\hline & & & $\begin{array}{l}\mathrm{X} \\
\text { (Median) }\end{array}$ & $\begin{array}{l} \pm \text { SS } \\
\text { (Standart deviation) }\end{array}$ & \\
\hline \multicolumn{6}{|l|}{ Gender } \\
\hline Girl & 253 & 65,2 & 27,64 & 8,65 & $\mathrm{t}=0,99 \mathrm{a}$ \\
\hline Male & 135 & 34,8 & 28,60 & 9,65 & $p=0,320$ \\
\hline \multicolumn{6}{|l|}{ Age } \\
\hline Between 18 and 20 & 270 & 69,6 & 28,92 & 9,19 & $t=3,16^{a}$ \\
\hline 21 years and older & 118 & 30,4 & 25,81 & 8,22 & $\mathrm{p}=0,002$ \\
\hline \multicolumn{6}{|l|}{ Economical situation } \\
\hline Good & 76 & 19,6 & 28,14 & 9,10 & $\mathrm{f}=0,36^{\mathrm{b}}$ \\
\hline Middle & 274 & 70,6 & 27,78 & 9,09 & $p=0,695$ \\
\hline $\mathrm{Bad}$ & 37 & 9,6 & 29,10 & 8,52 & \\
\hline \multicolumn{6}{|l|}{ Place of Residence } \\
\hline With family & 202 & 52,1 & 28,37 & 8,78 & \\
\hline Dormitary & 111 & 28,6 & 27,23 & 8,52 & $\mathrm{KW}=9,71^{\mathrm{c}}$ \\
\hline Student house & 50 & 12,9 & 30,04 & 1,44 & $\mathrm{p}=0,021$ \\
\hline Other & 23 & 5,9 & 23,39 & 1,96 & \\
\hline \multicolumn{6}{|l|}{ Time on the Internet } \\
\hline Between 0-4 hours & 218 & 56,8 & 25,55 & 7,92 & $t=6,28^{a}$ \\
\hline 5 hours and more & 166 & 43,2 & 31,12 & 9,41 & $\mathrm{p}=0,000$ \\
\hline \multicolumn{6}{|c|}{ Internet package in phone } \\
\hline Yes & 367 & 94,6 & 27,95 & 9,04 & $3534,5^{\mathrm{d}}$ \\
\hline No & 21 & 5,4 & 28,47 & 8,60 & $\mathrm{p}=0,523$ \\
\hline \multicolumn{6}{|l|}{ Body Mass Index } \\
\hline Lean & 27 & 7,0 & 30,77 & 9,73 & $\mathrm{KW}=4,37 \mathrm{c}$ \\
\hline Average & 299 & 77,1 & 28,01 & 8,89 & $p=0,112$ \\
\hline Fat & 62 & 16,0 & 26,61 & 9,11 & \\
\hline \multicolumn{6}{|c|}{ Eating attitude during internet usage } \\
\hline Yes & 233 & 60,1 & 30,22 & 9,19 & $t=6,31^{a}$ \\
\hline No & 155 & 39,9 & 24,60 & 7,58 & $p=0,000$ \\
\hline \multicolumn{6}{|l|}{ Sports } \\
\hline Yes & 218 & 56,3 & 27,21 & 8,56 & $\mathrm{t}=1,85^{\mathrm{a}}$ \\
\hline No & 169 & 43,7 & 28,92 & 9,50 & $\mathrm{p}=0,065$ \\
\hline \multicolumn{6}{|l|}{ Reading habit } \\
\hline Yes & 275 & 70,9 & 27,21 & 8,67 & $\mathrm{t}=2,61^{\mathrm{a}}$ \\
\hline No & 113 & 29,1 & 29,83 & 9,58 & $p=0,009$ \\
\hline
\end{tabular}

at test in independent groups, ${ }^{\mathrm{b}}$ ANOVA ${ }^{\mathrm{c}}$ Kruskal-Wallis ${ }^{\mathrm{d}}$ Mann-Whitney $\mathrm{U}$ test

The difference between; the ages of the students, the place they live in, eating attitude during internet usage, time spent on the internet and the YIAT-SF score average were statistically significant $(\mathrm{p}<0.05)$. The students who had eating attitude during internet usage $(30,22 \pm 9,19)$ and spent 5 hours or more on the internet $(31,12 \pm 9,41)$ had higher YIAT-SF scale point averages than the other groups (Table 4). The difference between; the gender of the students, economic status, body mass indexes, presence of internet package on the phone 
and the YIAT-SF score averages were not statistically significant ( $p>0.05)$. The difference between; reading status of the students and the YIAT-SF scale point averages showed statistically significant difference $(\mathrm{p}<0.05)$, average YIAT- SF scores of the students who had reading habit was lower than non-readers $(29,83 \pm 9,58)$ (Table 4$)$. The difference between sporting status and YIAT-SF scale point averages was not statistically different ( $p>0.05)$.

\section{Discussion and Conclusion}

Internet addiction ratios have been found to be between 0.5 and $8,2 \%$ in various studies (Derbyshire et al., 2013; Nath, et al., 2016), by being 3.4 \%our result is similar with those results. We have found problematic internet usage ratio to be $48.5 \%$, this result is similar with ratios of 30-46\% that were determined in different researches (Bianchini, Cecilia, Roncone \&Cofini, 2017; Nath, et al., 2016). Our results are also similar with a recent study done in Turkey -in which internet addiction ratio and problematic internet usage ratios of university students were determined as 4,5\% and \%52,8 (Filiz, et al., 2014).

In this study, we determined preferred internet sites as; social media platforms, movie sites, news sites, educational/ information sites, game sites, e-mail sites, shopping sites, sexuality sites, in order. Educational and informational content sites usage -as the first choice- $(20,2 \%)$ was in the fifth place. When we looked at recent studies about this topic, we saw similarities with our study in general (Ching, et al., 2017; Nath, et al., 2016). Similar to our result of 5,7\%, Ching and colleagues have found internet usage for educational purpose as 7,3\% (Ching, et al., 2017). In different studies done worldwide, social media usage was found to be firstly preferred and was between $69-74,4 \%$ in students (Filiz, et al., 2014; Nath, et al., 2016), this is similar to our result of 79.4\%. Although Ersun and et al. have found 'research sites' to be the first preferred (Ersun, et al., 2010), we can say that social media platforms are 7 to 10 times more preferred than educational content sites.

We had found 'daily internet usage' to be approximately 5 hours (Table 4). This result is higher than the comparative study in which; Korean and American college students' internet usage habits were compared and daily internet usage more than 3 hours was found to be $\% 17,7$ and $\% 17,8$ in two countries (Shin, 2014). This difference can be defined by 'increasing usage ratios of mobile phones in internet connection'.

Prasad and colleagues, in their study about nomophobia- strong addiction to mobile phone use-, have found internet usage to be more than 3 hours (Prasad, et al., 2017). 
Nomophobia as a new subject in terminology, is becoming a new topic in internet addiction. We had found that $94,3 \%$ of the students had internet connection in their mobile phones (Table 4) and $67,8 \%$ of them used internet mostly from their mobile phones. Our ratio about 'internet connection usage from mobile phone' was similar with different studies (Filiz, et al., 2014; Nath, et al.,2016,). In contrast to the findings of Prasad, we did not find statistically significant increase between 'internet connection on mobile phone' and internet addiction scores. Interestingly we determined that, $21 \%$ of the students defined school as the main internet restricting factor (Figure 1). Prasad and colleagues have found the tendency to use mobile phone internet connection in school as $24.7 \%$ (Prasad, et al., 2017). We think these two results are important points to focus and make researches on.

We found internet addiction score increasement with enhanced internet usage and our result show similarity with Oktan and Sırakaya's research (Sırakaya \& Seferoğlu, 2013).

When the gender and internet addiction is compared, different results have been found in studies. In Shin's comparative study, Korean girl college students were found to spend more time in internet but there was no difference in gender in America (Shin, 2014). In Turkey, male gender has been found to have tendency for internet addiction in many studies (Akdağ, et al., 2014; Sirakaya \& Seferoğlu, 2013). We didn't find statistical difference between gender and YIAT-SF scores (Table 4) and this is similar with different studies made among college students (Bianchini, et al., 2017; Han, et al., 2017; Filiz, et al., 2014).

Family support is a meaningful positive factor in supporting the students academic performance. We tried to find whether the students who were living apart from their family had different internet usage habits. We found that, the students who lived in dormitories had statistically higher YIAT- SF scores when compared with the students who were living with their families (Table 4). This result shows similarity with Akdağ, Tao and Romiani's researches in which they found dormitories to be a risk factor for problematic internet usage (Akdağ, et al., 2014; Tao, Wu \& Wang, 2016). Besides internet addiction, Tao also defined dormitories as risk factors for anxiety and binge eating (Tao, et al., 2016). As internet addiction is defined to be accompanied by several psychological problems as; self-doubt, anxiety, and depression (Niven, Fawkner, Knowles, Henretty \& Stephenson, 2009), this result gives an important point to focus on.

Physical activity is important for better academic performance (Flueckiger, Lieb, Meyer,\& Mata, 2014). Li and colleagues have shown internet overuse and academic under- 
achievement to co- exist in university students. Besides, problematic internet usage has been shown to be a risk factor for decreased physical activity (Derbyshire, et al., 2013). In our study we didn't find statistical significant difference between internet usage and physical activity (Table 4). Although problematic internet users had been found to have higher BMI in different studies (Sarı \& Aydın, 2014), we also didn't find a relation between internet usage and BMI.

Problematic eating behaviors increase with increased usage of internet (Kaewpradub, Kiatrungrit, Hongsanguansri, \& Pavasuthipaisit, 2017). When we asked about eating attitude during internet usage, we found statistical difference with higher internet addiction scores (Table 4). Even though we did't find significant difference between BMI and internet addiction scores, we think BMI, eating attitude and problematic internet usage are important topics to make detailed researches on.

Students who had reading habit had lower YIAT- SF scores in our research. This result is similar with Şaşmaz and colleagues' research with high school students (Şaşmaz, et al., 2014). We believe that this factor is important in prevention and even in treatment of problematic internet usage.

As the result; despite the increase in computer and internet usage among students, it is seen that usage of internet for education is not common as expected. The reason for this condition is; lack of basic knowledge about educational sites usage and lack of adequate internet access. In order to increase computer and internet usage in students' education, the educators in different fields should be educated about; internet, new technologies, internet using skills and the students should be made aware of effective internet usage. Including our university, a lot of universities make some common lessons in internet environment. Besides common lessons, the educators shall prepare appropriate internet sites for spesific lessons and encourage the students to use these sites. The students shall reach course contents and the other sites -which give necessary information about spesific topics- from these sites. Also the students shall discuss the lessons online for 24 hours in these sites, and they shall be encouraged to prepare homeworks and researches from internet. To do these, the physical environment for computer use shall be improved- not only in schools, but also in dormitories and libraries-. Also places for computers and printer usage shall be organised by the needs of students. 


\section{Limitations}

The fact that the survey includes only the students among population, only one school of the university -therefore the perspectives of the other sections of the society are not reflected- can be considered as the limitation of this research.

\section{References}

Akbaba, S., \& Altun, A. (2000). Bir eğitim aracı olarak internet. Milli Ĕğitim Dergisi, 147, 23-26.

Akdağ, M., Şahan Yılmaz, B., Özhan, U., Şan, İ. (2014). Üniversite öğrencilerinin internet bağımlılıklarının çeşitli değişkenler açısından incelenmesi (inönü üniversitesi örneği). İnönü Üniversitesi Eğitim Fakültesi Dergisi, 15 (1), 73-96.

Altun, A. (2003). Elektronik okuryazarlık. Milli Ĕ̆gitim Dergisi, 158, 1-9.

Arıkan, Y. D., \& Altun E. (2007). A research on preschool and primary student-teachers' use of online homework sites. Elementary Education Online, 6(3), 366-376.

Bianchini, V., Cecilia, M.R., Roncone, R., \& Cofini, V. (2017). Prevalence and factors associated with problematic internet use: an italian survey among L'Aquila students. Riv Psichiatr., 52 (2), 90-93.

Chen, Q., Quan, X., Lu, H., Fei, P., Li, M. (2015). Comparison of the personality and other psychological factors of students with internet addiction who do and do not have associated social dysfunction. Shanghai Arch Psychiatry, 27(1), 36-41.

Ching, S.M., Hamidin, A., Vasudevan, R., Sazlyna, M.S., Wan Aliaa, W.S., Foo, Y.L., Yee, A., \& Hoo, F.K. (2017). Prevalence and factors associated with internet addiction among medical students - A cross-sectional study in Malaysia. Med J Malaysia, 7-11.

Derbyshire, K.L., Lust, K.A., Schreiber, L.R., Odlaug, B.L., Christenson, G.A., Golden, D.J., \& Grant, J,E. (2013). Problematic internet use and associated risks in a college sample. Compr Psychiatry, 54(5), 415-422.

Dursun, F., (2004). Üniversite öğrencilerinin interneti kullanım amaçları. XIII. Ulusal Eğitim Bilimleri Kurultayı, 6-9 Temmuz 2004, İnönü Üniversitesi, Eğitim Fakültesi, Malatya.

Ergün, M. (1998). İnternet destekli eğitim. Afyon Kocatepe Üniversitesi Sosyal Bilimler Dergisi, $1,1-10$.

Ersun, A., Şahin Köze, B., Muslu, G., Beytut, D., Başbakkal, Z., \& Conk, Z. (2012). Hemşirelik yüksekokulu öğrencilerinde internet kullanımı ile sosyal destek sistemi arasındaki ilişkinin incelenmesi. İ.Ü.F.N. Hem. Derg., 20 (2), 86-92.

Filiz, O., Erol, O., Dönmez, F.İ., \& Kurt, A.A. (2014). BÖTE bölümü öğrencilerinin sosyal ăg siteleri kullanım amaçları ile internet bağımlılıkları arasındaki ilişkinin incelenmesi. Journal of Instructional Technologies \& Teacher Education, 3 (2), 17-28.

Flueckiger, L., Lieb, R., Meyer, A.H., \& Mata, J. (2014). How health behaviors relate to academic performance via affect: an intensive longitudinal study. PLoS One, 9(10), $1-10$. 
Han, P., Wang, P., Lin, Q., Tian, Y., Gao, F., \& Chen, Y. (2017). Reciprocal relationship between internet addiction and network-related maladaptive cognition among chinese college freshmen: a longitudinal cross-lagged analysis. Front Psychol., p. 1047.

IWS. World internet usage and population statistics, (2017)- Update. http://www.internetworldstats.com/. Date of access: 14.07.2017

Kaewpradub, N., Kiatrungrit, K., Hongsanguansri, S., \& Pavasuthipaisit, C. (2017). Association among internet usage, body image and eating behaviors of secondary school students. Shanghai Arch Psychiatry, 29 (4), 208-217.

Kutlu, M., Savcı M., Demir, Y., \& Aysan, F. (2016). Young internet bağımlılığı testi kısa formunun türkçe uyarlaması: üniversite öğrencileri ve ergenlerde geçerlilik ve güvenilirlik çalışması. Anadolu Psikiyatri Dergisi, 17, 69-76.

Naseri L, Mohamadi J, Sayehmiri K, \& Azizpoor Y. (2015). Perceived social support, selfesteem, and internet addiction among students of al-zahra university, tehran, iran. Iran J Psychiatry Behav Sci., 9(3), e421. doi: 10.17795/ijpbs-421.

Nath, K., Naskar, S.,Victor, R. (2016). A cross-sectional study on the prevalence, risk factors, and ill effects of internet addiction among medical students in northeastern india. Prim Care Companion CNS Disord., 18 (2).

Niven, A., Fawkner, S., Knowles, A.M., Henretty, J., Stephenson, C. (2009). Social physique anxiety and physical activity in early adolescent girls: the influence of maturation and physical activity motives. J Sports Sci.,27 (3), 299-305.

Savcı, M. (2017). Ergenlerin sosyal zekâ, sosyal kaygı, akran ilişkileri, internet bağımlılı̆̆1 ve sosyal bağlllık düzeyleri arasındaki ilişkiler. Dokuz Eylül Üniversitesi Ĕ̆itim Bilimleri Enstitüsü Ĕ̆itim Bilimleri Anabilim Dalı Rehberlik ve Psikolojik Danışmanlık Programı, Doktora Tezi, İzmir.

Pawlikowski, M., Altstötter-Gleich,C., \& Brand, M. (2013). Validation and psychometric properties of a short version of young's internet addiction test. Computers in Human Behavior, 29(3), 1212-1223.

Prasad, M., Patthi, B., Singla, A., Gupta, R., Saha, S., Kumar, J.K., Malhi, R. \& Pandita, V. (2017). Nomophobia: a cross-sectional study to assess mobile phone usage among dental students. J Clin Diagn Res., 11(2), ZC34-ZC39.

Sarı, S.V., \& Aydın, B. (2014). Problematic internet use and body mass index in university students. Eurasian Journal of Educational Research, 54, 135-150.

Şaşmaz, T., Öner, S., Kurt, A.Ö., Yapıc1, G., Yazici, A.E., Buğdayc1, R., \& Sis, M. (2014). Prevalence and risk factors of internet addiction in high school students. Eur J Public Health, 24(1), 15-20.

Sırakaya, M., \& Seferoğlu, S. (2013). Öğretmen adaylarının problemli internet kullanımlarının incelenmesi. Hacettepe Üniversitesi Ĕ̆itim Fakültesi Dergisi, 28(1), 356368.

Shin, L.Y. (2014). A comparative study of mobile internet usage between the u.s. and korea. Journal of European Psychology Students, 46-55. 
Yaknct, Gürbüz \& Yetiş

Tao, Z., Wu, G., \& Wang, Z. (2016). The relationship between high residential density in student dormitories and anxiety, binge eating and Internet addiction: a study of chinese college students. Springerplus., 5(1), 1579.

Young, K.S. (1998). Internet addiction: The emergence of a new clinical disorder. CyberPsychology \& Behavior, 1, 3. 